\title{
Byznys jako povolání? Některé etické a duchovní souvislosti bohatství a moci
}

Roman Míčka

Podtitul „etické a duchovní souvislosti bohatství a moci“ je možná přiliš široký a velkorysý, nenízde pochopitelně možné obsáhnout celou širîi takto pojatého tématu, ani se pokusit o snadnou syntézu aspektů biblických, teologických, etických, politických a ekonomických. Z biblického hlediska je možné pohled na bohatství zjednodušovat na hledání jakéhosi napětí mezi podobenstvím „O velbloudu a uchu jehly" (M† 19,23-26), který je častým duchovním argumentem proti bohatství křestana, přes podobenství „O dělnících na vinici“ (M+20,1-16) dostávajících , po socialistickém zpưsobu“ tutéž mzdu bez ohledu na množství odvedené práce, až po „Podobenství o hřivnách“ (M† 25, 14-30), kde jsou služebníci hodnoceni dle tvrdých kapitalistických měřitek výhradně s utilitárním ohledem na schopnost zhodnocení svěřeného majetku, bez jakékoli zmínky o etických ohledech. Poselství zmíněných podobenství není možné primárně chápat jako směřující do oblasti ekonomických vztahů, ale jako vyjádření určitých duchovních aspektů Ježišem hlásaného Božího království. Ze znění prvního podobenství přesto lze skromně usuzovat, že bohatí budou souzeni shovívavě, s ohledem na odpovědnost a zátěž, která je jim svěřena, a také s ohledem na to, co si mưžeme vzít z posledně jmenovaného podobenství, totiž že je jim dáno navíc to, co je odňato oněm méně zpưsobilým a schopným. Na hrůzu učedníků, kłerou u nich vzbudil obraz velblouda procházejícího uchem jehly, Kristus totiž reaguje ve věci spásy takto: "U lidí je to nemožné, ale u Boha je možné všecko". Napětí mezi těmito podobenstvími vyjadřuje i napětí mezi způsoby povolání křestana k veřejnému životu a k ekonomické činnosti'. Někteři jsou povoláni k chudobě a k životu služby druhým, která je ovšem často finančně závislá na benevolenci bohatých či dnes spíše na organizační moci státu, jiní mohou býł povoláni k odpovědnosti za vyłváření a správu bohatství, které je nezbytným atributem společného dobra a potenciálem af již dobrovolné, nebo nedobrovolné solidarity.

Křestanství straní chudým, je do značné míry opcí pro chudé, nabádá proti závislostem člověka nejen na majetku, ale i na všech pozemských skutečnostech. Nelze sloužit dvěma pánům - "Nemůžete sloužit Bohu i mamonu" (Mt 6,24). $\checkmark$ některých případech a pro někoho, kdo není schopen obstát $v$ této těžké zkoušce, Kristus doporučuje zbavit se majetku úplně, ale tato výzva ,jdi, prodej, co ti patři, rozdej chudým" (M† 19,21) není v křestanské etické tradici považována obvykle za univerzální, leč náležící pouze onomu Bohatému mladíkovi. Vztah k majetku má býł z hlediska křestanství, analogicky k jiným oblastem lidského života a pozemských skutečností, rezervovaný a nesmí nahradit či vytěsnit vztah k Bohu, člověk musí býł od pozemských skutečností svoboden a ne na nich býł závislý. Jako analogie se často uvádí Kristova výzva ke zřeknutí se otce, matky, ženy a dětí ve prospěch Krista (srov. L 14,26), která nemá znamenat odvrhnutí rodinných př́slušníků, ale apel na správnou hierarchii hodnot. Vztaženo prímo k majetku mủžeme dokonce najít výrok varující před přitažlivostí bohatství: „Láska k penězưm je totiž kořenem všeho zla, v honbě za nimi někteři zbloudili z cesty víry a sami si zpưsobili nezměrné trápení. Ty ale jako Boží člověk od takových věcí utíkej a následuj spravedlnost, zbožnost, víru, lásku, trpělivost a mírnost" (1 Tm 6,10-11). 
Křestanství je samožejmě na prvním místě ze sociálního hlediska „opcí pro chudé“, Ježǐš straní chudým avyzývák vysvobozenízpoutzávislostína majetku. Jako „opce pro chudé" by se však nemělo stát automaticky jakousi "opcí proti bohatým", nemělo by primárně legitimizovat odnímání majetku a jeho nedobrovolnou redistribuci, jak se někdy děje i v intencích určitých forem křestansky orientované sociální etiky. Záměrem je na prvním místě poukázat $v$ souvislosti s tématem „pastorace bohatých" na problematičnost ambivalentního, často až nenávistného postoje k bohatým a mocným tohoto světa, na místě druhém využít některé výrazné podněty ze slavné knihy Michaela Novaka Byznys jako povolání (1996)², v níž se autor pokouší byznys duchovně rehabilitovat.

\section{Když se rozmnožuje jomění, množí se i přiživníci}

Odpovědná správa a rozmnožování majetku je totiž výrazným příspěvkem ke společnému dobru. Moderní kapitalismus, jehož obhájci poukazují na enormní dynamiku postupného vykořeňování chudoby zřetelně patrného $\mathrm{v}$ každé další následující generaci, je předmětem ambivalentních hodnocení. Petr Berger kupř́kladu ř́ká ve své knize Kapitalistická revoluce, že kapitalismus „....uvolnil největší produktivní sílu v dějinách lidstva. Dosud žádný jiný sociálně ekonomický systém nebyl schopen vytoořit srovnatelnou produktioní silu“"3. Obhájce kapitalismu, katolický teolog Michael Novak velkolepě dodává: „Po pěti tisíciletích tápání lidé konečně přišli na to, jak dosahovat bohatství trvalým a systematickým procesem "4. "Po svém vyhnání ze zahrady Edenu stanul Adam tvář́ v tvář světu, který nechával lidstvo po celá staletí strádat a hladovět. Dnes je tajemství trvalého materiálního pokroku rozluštěno. Zodpovědnost za zmírnění strádání a hladu již nenese Bưh, ale my sami“" ${ }^{\prime \prime}$ Oba autoři naznačují, že celé předkapitalistické dějiny nebyly nakloněny vykořeňování chudoby a tvorbě důstojných materiálních životních podmínek lidí. Kličovými pro tento expanzivní vzestup bohatství jsou kdo jiní, než kapitalisté - podnikatelé, kteří se obvykle př́liiš nerekrutovali ze starých premoderních bohatých aristokratických elit, nýbrž obvykle z měštanské vrstvy spíše chudší střední tř́idy. Tito lidé neobjevili odedávna respektovaný princip soukromého vlastnictví, ani neobjevili odedávný obchod a trh, nebyli první, kdo akumulovali zisk. Neobjevili ani chamtivost a nenasytnost, kterou považují někteř́ za inovaci při vzniku kapitalismu, tento hř́ch doprovází lidstvo od počátku. Kapitalismus má totiž původ v lidské schopnosti invence a inovace - v lidské kapacitě tvořit. Jak napovídá samotné slovo „kapitalismus“ - jde o systém institucí, který má za cíl uvolnit kreativní síly v člověku a využít ctnosti praktického rozumu. Kapitalismus je založený na myšlení na správném použivání lidské mysli - hlavy - „caput“. Slovo kapitalismus tedy podle této interpretace neodkazuje primárně na peníze, ale na "lidský kapitál“ - znalost, vynalézavost, know-how, iniciativu, podnikavost, kapacitu k organizaci, schopnost kooperace. Kapitalismus je spojen s určitým étosem, o kterém měl Max Weber za to, že pramení z kalvínské úzkostné náboženské neurózy, Novak se naproti tomu domnívá, že centrální pro kapitalismus je právě kreativita. Kreativitu považuje Novak za centrální bod katolické, nikoli protestantské etiky, což se snaží obhájit ve své knize The Catholic Ethic and the Spirit of Capitalism (1993) ${ }^{6}$.

Nové elity - bohatí současnosti - kapitalisté se však navzdory zjevnému společenskému př́nosu netěší př́liš velké úctě. Pro současnost je typický pohled na bohaté a mocné spíše jakožto na

2 Michael NOVAK, Business as a Calling. Work and the Examined Life, New York: The Free Press, 1996.

3 Peter L. BERGER, Kapitalistická revoluce: padesát propozic o prosperitě, rovnosti a svobodě, Bratislava: Archa, 1993, s. 61-62.

4 Michael NOVAK, Duch demokratického kapitalismu, Praha: Občanský institut, 1992, s. 17.

5 Tamtéž, s. 28.

6 Srov. Michael NOVAK, The Catholic Ethic and the Spirit of Capitalism, New York: The Free Press, 1993. 
zloděje a parazity společnosti, než na její výrazné přispěvatele a spolutvůrce společného dobra. Tento veskrze pokřivený pohled může mít racionální jádro i částečné opodstatnění $\mathrm{v}$ často opomíjeném aspektu rozlišení mezi zpo̊soby nabývání bohatství ve smyslu jisté legitimity. Mnozí podnikatelé, kteří výrazně zbohatli, založili své podnikání skutečně na kreativním př́nosu v určité oblasti lidské činnosti, a přispěli tak k rozvoji společnosti. Naproti tomu existuje poměrně široká vrstva podnikatelských aktivit nekreativního charakteru, tedy těch, které participují na korupční kooperaci se státem a veřejnými institucemi. Tento aspekt, málo zmiňovaný a rozlišovaný, zdůrazňuje kupříkladu ekonom Pavel Kohout v článku Proč ekonomika stagnuje $^{7}$, kde na základě díla ekonomů Jamese Robinsona a Darona Acemoglu ${ }^{8}$ kromě jiného rozlišuje mezi elitami kreativními a extraktivními. Kreativní elity zbohatli vlastní inteligencí, tvořivostía pílí, extraktivní elity bohatnou na základě podezřelých privatizací, zmanipulovaných státních zakázek, dotací a děr v zákonech. Je zřejmé, že liberální ekonomové jako Novak, již $\mathrm{s}$ ohledem na zdůrazňovaný kreativní rozměr kapitalismu nebudou nakloněni nekreativním formám získávání bohatství, $\mathrm{v}$ němž ostatně často silnou roli sehrává stát a korupce $\mathrm{v}$ rámci jeho institucí, nikoli svobodné a konkurenční tržní prostředí. Silný stát, množství veřejného majetku a veřejných peněz (privatizace, veřejné zakázky, eurodotace, ekologické dotace apod.) mnohdy právě napomáhají vzniku „extraktivních elit“ na úkor kreativních.

Bez ohledu na charakter podnikatelských aktivit si státy se svou vzestupující mocí v průběhu dvacátého století, zejménajeho druhé polovině, často braly bohaté ekonomické elityjako rukojmí svých sociálních experimentů a jako významný zdroj př́ijmů. Sazba progresivní daně činila v některých zemích, kupříkladu v předthatcherovské Británii 83\%, ovšem efektivní mezní míra zdaněn činila až neskutečných 95 \%, v předreaganovských USA byla horní sazba daně z př́ijmu $70 \%$. Následovala éra, která byla daňově příznivější, ovšem v současnosti, kdy se v dobách krize a v situaci dynamické globalizace ukazuje perspektivní neudržitelnost stávající hladiny veřejných výdajů, nároků a sociálních vymožeností přebujelého státu blahobytu, se politici opět více ptají po tom, koho a jak radikálněji zdanit a ještě tím jako bonus získat popularitu u voličů. Živým příkladem je návrh 75 \% „daně pro bohaté“ francouzského prezidenta François Hollanda. Nelze než nevzpomenout v této souvislosti alespoň jeden citát ze Starého zákona, z již v tomto čísle časopisu rozebírané knihy Kazatel: „Když se rozmnožuje jmění, množi se i př́živníci. Jaký prospěch z toho mívá vlastník? Ledaže se na to může dívat" (Kaz 5,10).

„Bohatí Američané by měli platit vyšši daně ${ }^{\text {" }}$, prohlásil v prvním povolebním projevu Obama, a to $\mathrm{v}$ situaci, kdy deset procent Američanů s nejvyššími př́ijmy platí z celkového výnosu daně z př́ijmu 45,1 \% a v situaci, kdy takřka polovina (47\%) Američanů neplatí daň z př́jimu žádnou. V tomto kontextu je třeba se oprávněně ptát, kde jsou hranice legitimního zdanění a přerozdělování bohatství mezi všechny, zejména od těch, jejichž příjmy (a tudíž i schopnosti, iniciativa a kreativita) jsou považovány za společné jmění, které je možné si kdykoli ze strany státu a ostatních občanů nárokově přivlastnit. Proti nadměrným očekáváním vưči potenciálu řešit sociální problémy odnímáním a přerozdělováním bohatství, případně vyvolávání „trřídní nenávisti“ se vyslovovala již první sociální encyklika při kritice socialistických ideálů: „,...socialisté, podnítivše nenávist chudých proti bohatým, prohlašují, že se má soukromé vlastnictví zrušit a misto toho $z$ majetku jednotlivců učinit společný majetek všech a že by jej spravovali ti, kdo stojí v čele obcí nebo státì. (...) Avšak jejich plán je naprosto nezpůsobilý tento rozpor úspěšně vyřešit; dokonce by znamenal

\footnotetext{
7 Srov. Pavel KOHOUT, Proč ekonomika stagnuje (on-line), dostupné na: http://www.novaustava.cz/clanky/proc-ekonomika-stagn, citováno dne 19. 8. 2013.

8 Srov. Daron ACEMOGLU, James ROBINSON, Why Nations Fail: The Origins of Power, Prosperity, and Poverty, New York: Crown Publishers, 2012.

9 Srov. Bohatí Američané by měli platit vyšší daně, prohlásil v prvním povolebním projevu Obama (on-line), dostupné na: http:// www.rozhlas.cz/zpravy/amerika/_zprava/bohati-americane-by-meli-platit-vyssi-dane-prohlasil-v-prvnim-povolebnim-projevuobama--1135177, citováno dne 3. 7. 2013.
} 
pro dělnické vrstoy poškození. Mimoto je nespravedlivý, protože se dopouští násilí na zákonných majitelích. Vnáší zmatek do života státu tím, že ukládá státní moci úkoly, které jí nepř́slušeji" ${ }^{\text {u10. }}$ Určitým paradoxem je, že bohatí, kteří svo̊j majetek získali jinou než podnikatelskou činností (umělci, sportovci apod.) nejsou pod tak silným tlakem společnosti a nad jejich bohatstvím není činěn tak silný moralizující otazník.

\section{Novakova kniha Business as a Calling}

A nyní již k Novakově knize Business as a Calling - Work and the Examined Life (1996), v níž se autor pokusil svět byznysu i byznysmeny samotné alespoň částečně duchovně rehabilitovat a upozornit na křest'anský rozměr povolání v byznysu.

Jako teolog si Novak nejprve všímá silné antikapitalistické tradice v rámci křestáanství - stálý odpor mnohých křest́anských myšlenkových směrů i představitelů hierarchie podle něj hluboce souvisí se silnou „,antikapitalistickou tradicí“ , která má ještě kořeny v dobách, kdy byla církev finančně závislá na starých premoderních elitách, na aristokracii feudálního charakteru. Za další kořen odporu vůči světu podnikání a byznysu považuje Novak intelektuály, jejichž vzdělanost byla spojena s aristokratickou tradicí svobodných umění a společenských věd ${ }^{11}$. Od samého vzniku a počátků rozvoje kapitalistického hospodářství v devatenáctém století se intelektuálové celého světa vydali na pochod proti svobodnému trhu. „Intelektuálové od těch dob nacházeli zvláštní radost definováním business class za třídního nepřitele číslo jedna, za ztělesnění a príčinu sociálního zla"12. Intelektuálové si podle něj zvykli identifikovat se s aristokracií, jsou to „šlechticové ducha“ pohrdající vulgární vrstvou „maloměštákůu a novozbohatlíků pěstujících „buržoazní" nearistokratickou morálku a odmítající nízký a materialistický svět byznysu. S tím souvisí i odraz vnímání podnikatelských elit ve sféře filmového umění - do 60. let byl americký byznysmen v holywoodských filmech většinou prezentován jako pozitivní postava, od 70. a 80. let zejména jako darebák, ničema a zloděj ${ }^{13}$. Za další kořen odporu vůči kapitalismu a kapitalistům považuje Novak prostou závist, kterou považuje za jednu z nejničivějších společenských sil a která se projevuje stálými důrazy na spění k materiálnímu rovnostářství ${ }^{14}$.

Novak široce poukazuje na smutný, nevděčný a obtížný úděl lidí pracujících ve světě byznysu. Vủči podnikatelské sféře a angažovanosti panují mnohé předsudky a mýty, jako ostatně proti celému kapitalistickému systému hospodářství. Lidé pracující ve světě byznysu, zejména ti úspěšnější a bohatší, jsou vnímáni jako morálně podezřelí, usilující výhradně o zisk. Podnikatelská aktivita nemá v očích mnohých valnou duchovní hodnotu, zkreslený mediální obraz o ní budí dojem, že s touto aktivitou jsou téměř nerozlučně spojeny vlastnosti jako žádostivost, chamtivost, vulgarita, nepoctivost. Novak si ovšem nečiní iluze o realitě a praktikách existujících ve světě byznysu, nicméně nepovažuje systém a lidi v něm se angažující za nutně nemorální a zlé. Pokouší se obhájit moralitu podnikání, přičemž angažovanost v ekonomické sféře považuje dokonce za "poslání“ v náboženském smyslu. „Kariéra v byznysu je nejenom morálně závažným posláním, ale i morálně vznešeným posláním. Ti, co jsou k němu povoláni, mají dưvod k hrdosti a radosti ${ }^{\prime 15}$. Poukazuje taktéž na to, že ve Spojených státech dokonce podle sociologických průzkumů patří jedinci pracující ve světě byznysu, společně s vojáky a sportovci,

\footnotetext{
10 Rerum novarum, čl. 3.

11 Srov. Michael NOVAK, Business as a Calling, s. 5.

12 Tamtéž, s. 55.

13 Srov. tamtéž, s. 7-10.

14 Srov. tamtéž, s. 90-92.

15 Tamtéž, s. 13.
} 
mezi osoby s nejvyšší mírou religiozity ${ }^{16}$. Je to snad proto, že je v těchto profesích faktor úspěchu spojen s velkými riziky a s náhodnými faktory působícími mimo sféru vlivu jednotlivce.

Tvorba bohatství není podle Novaka morálně neutrální, ale apriorně morálně správný zpưsob naplnění osobní odpovědnosti. Byznys lze uskutečňovat morálním i nemorálním zpưsobem, jakož i jiné oblasti činnosti, kde je dán prostor lidské svobodě. Systém kapitalismu je stejně jako veškerá jiná lidská činnost zasažen lidským hříchem, není to ovšem důvod $\mathrm{k}$ jeho eliminaci či zásadní reorganizaci a regulaci. Nutkání k osobní ekonomické iniciativě je vyjádřením přirozené svobody a je nutné mu ustavit vhodný institucionální rozměr. Kulturně morální dimenze systému demokratického kapitalismu je však $v$ úpadku a je třeba usilovat o její oživení. Formování charakteru, které bylo po celé generace prvořadou funkcí vzdělávacích institucí, se vytratilo - ctnost byla nahrazena morální neutralitou. Ctnost by se však měla dle Novaka stát životním zájmem byznysu, a to i z čistě pragmatických důvodů - morálka firmy je investicí a devízou pro její perspektivní prosperitu, i když z krátkodobého hlediska může mít větší úspěch ekonomické jednání bez morálních ohledů. Novak se dokonce v tomto smyslu pokouší o definici tři „kardinálních ctností byznysu“, které by v nové situaci moderní doby pomohly doplnit klasicky definované ctnosti. Píše, že „...etika byznysu je mnohem větší výzvou, než jen dodržování občanských zákonů a neporušování morálního zákona. Znamená to vizi a vybudování nového typu světa, založeného na principech osobní tvořivosti, společenství, realismu a dalšich ctností podnikání. Znamená to respektování práva chudých na vlastní osobní ekonomickou iniciativu a jejich vlastni tvořivost. Znamená to vytvořeni kultury hodné svobodných mužu a svobodných žen - ve prospěch chudých a $k$ větší slávě Boži" ${ }^{17}$.

Za kardinální ctnosti byznysu Novak považuje ${ }^{18}$ zejména jím akcentovanou kreativitu, tvořivost, která je podpořená habity jako odvaha, tvrdá práce a vytrvalost. Je to hlavní ctnost, která startuje a udržuje celý systém utváření bohatství. Zatímco dříve byla primárním faktorem bohatství zemědělská půda a přírodní bohatství, dnes jsou tyto faktory pro rozvoj bohatství druhořadé, až nepodstatné. Hlavním zdrojem bohatství je intelektuální kapitál ${ }^{19}$. Cllověk jako imago Dei je povolán dynamicky dotvářet a přetvářet stvořený svět. Další ctností byznysu je budování společenství - podpořené habity jako čestnost, velkodušnost a cit pro spravedlnost. Téměř veškerá práce a tvořivá činnost je vykonávaná pro někoho jiného, člověku byla Bohem dána kapacita vytvořit $\mathrm{v}$ životě víc, než spotřebuje. Toje předpokladem ekonomického pokroku a vzájemného obohacení. Moderní obchodní systém je výrazem vzájemné provázanosti lidstva, jak naznačoval již Jan Zlatoústý ${ }^{20}$. Třetí ctností byznysu je podle Novaka praktický realismus - podpořený habity jako schopnost naslouchat, být pozorný a vnímavý, schopnost uvažovat $\mathrm{v}$ širších souvislostech, být sebekritický a ochotný uznat svoje chyby. Je to ctnost blízká kardinální ctnosti praktické moudrosti (phronesis).

Novak relativizuje roli státu při vytváření uspokojivých životních podmínek a pracovních míst, roli byznysu považuje naopak za klíčovou a říká: „Byznys je nejlepši a jedinou reálnou naději chudých. Pozdvižení chudých z jejich bídy patří mezi nejušlechtilejší poslání byznysu“ "21. Zatímco státy, zejména $\mathrm{v}$ průběhu několika posledních desetiletí, vytvářejí aktivně závislost občanů na svých strukturách, přerozdělovacích a dotačních mechanismech, byznys může být arénou svobody a emancipace od státu při budování nezávislé občanské společnosti. Novak říká: „Pracovní

\footnotetext{
16 Srov. tamtéž, s. 43-45.

17 Tamtéž, s. 133.

18 Srov. tamtéž, s. 117-133.

19 Srov. Centesimus annus, čl. 32.

20 Srov. Michael NOVAK, Business as a Calling, s. 38-39.

21 Tamtéž, s. 37.
} 
př́ležitosti jsou pro chudé cennější, než almužna od vlády, která se k nim chová jako k nevolníkům" ${ }^{22}$. Jinde říká: „Povolání byznysu je jedinečně nejstrategičtějši povolání na díle sociální spravedlnosti. Je to povolání nejdůležitější k vymaněni chudých z chudoby. Byznys vytváři práci tam, kde predtím neexistovala “23. Podle Novaka by měl stát v dobře organizované svobodné demokratické společnosti plnit sice důležité, leč velmi omezené funkce. K byznysu v této souvislosti říká: „V projektu samosprávy je byznys nepochybně největší institucí občanské společnosti. Morální zdraví společnosti proto do velké míry závisí na morálním charakteru vůdcủ byznysu“ ${ }^{24}$.

Novak na mnoha místech chválí papeže Jana Pavla II., který si podle něj dal záležet, aby morálně rehabilitoval význam a poslání byznysu a podnikatelů, cituje kupř́kladu jeho proslov v Miláně z roku 1983: „Stupeň blahobytu, jemuž se těši současná společnost, by byl nemyslitelný bez dynamické osobnosti podnikatele, jehož funkce spočívá v tom, že organizuje lidskou práci a výrobní prostředky, aby produkovaly zboži a služby nezbytné pro společenskou prosperitu a pokrok" ${ }^{25}$.

\section{Kapitalista - hrdina současnosti?}

Z hledisek sociální spravedlnosti je třeba poznamenat, že bohatí občané by se měli přiměřeně podílet na rozvoji společnosti a systematicky přispívat na integrální společenský rozvoj. Existuje ale závažná otázka po hranicích solidarity, které musí být nastaveny spravedlivé meze. Sociální spravedlnost podle encykliky Quadragesimo anno (1931), skutečně znamená určitou míru přerozdělování a eliminaci extrémních společenských nerovností: „Každému at’ se tedy přiděli jeho podíl na statcích; a musí se usilovat o to, aby se rozdělení pozemských statků provedlo a upravilo podle zásad obecného blaha neboli sociální spravedlnosti. Dnes je však veliký protiklad mezi malým počtem velkých boháču a nesmírným množstvím chudáků a v rozdělení majetku je tedy velmi vážný nesoulad, jak vidi každý, kdo nepostrádá cit" ${ }^{26}$. Nejnovější sociální encyklika Benedikta XVI. Caritas in veritate (2009) tento přístup v jistém smyslu potvrzuje: „Trh je podř́zen principưm takzvané komutationi spravedlnosti, která rúdi právě vztahy dáváni a prijímání mezi rovnocennými partnery. Sociální učení církve však nikdy nepřestalo zdůrazňovat význam spravedlnosti distributivní a spravedlnosti sociální pro samotnou tržní ekonomiku, a to nejen proto, že tržní ekonomika je součástí širšího sociálního a politického propojeni, ale také kvưli soustavě vztahů, v nichž se uskutečňuje ${ }^{\text {¿27. }}$

Nastranědruhénenímožnéplněpřistoupitnaformulacidistributivníchideálů,jakjepředstavuje kupříkladu John Rawls - jádrem jeho teorie spravedlnosti je výrok: "Sociální a ekonomické nerovnosti maji být uspořádány tak, aby sloužily maximálnímu prospěchu nejméně zvýhodněných občanư". Toto může být žádoucí v situaci, která ohrožuje chudobou důstojnost a základní práva člověka, nikoli však v kontextu blahobytných společností, které vysoce sofistikovanými a redistributivními nástroji směřují k deformovanému ideálu kvality života vycházejícímu z neoprávněných nároků a sociálních práv. Rawlsova teorie spravedlnosti je materialistickou redukcí převádějící problémy spravedlnosti, lidských práv a demokracie na instrumentální úroveň uceleného zajišt'ování blahobytu a stejných příležitostí pomocí institucionálního zř́zení ${ }^{28}$. Takové pojetí spravedlnosti je redistributivním automatem, který nezná hranic a nezná

\footnotetext{
22 Tamtéž, s. 57.

23 Michael NOVAK, The Universal Hunger for Liberty. Why the Clash of Civilizations Is Not Inevitable, New York: Basic Books, 2004 , s. 52.

24 Michael NOVAK, Business as a Calling, s. 53.

25 Michael NOVAK, Katolické sociální myšlení a liberální instituce, Praha: ČKA, 1999, s. 225.

26 Quadragesimo anno, čl. 58.

27 Caritas in veritate, čl. 35 .

28 Srov. Samuel SCHEFFLER, The Appeal of Political Liberalism (on-line), dostupné na: http://ebookbrowse.com/scheffler-the-appeal-ofpolitical-liberalism-pdf-d347933808, citováno dne 3. 7. 2013.
} 
morální korektivy tázající se po uměřenosti blahobytu, konzumu a zcela se vymyká principu subsidiarity. Solidarita ve společnosti nemůže spočívat ve stálém hledání redistributivních nástrojů k umenšování rozdílů ve společnosti, ale právě v zabezpečování skutečně minimálních lidsky důstojných základních podmínek s ohledem na princip subsidiarity. Samozřejmě že definice chudoby a nedůstojných podmínek lidského života se částečně odvozuje od relativních měřítek vyspělosti té které společnosti, neměla by se ale nikdy stát nástrojem pro expanzivní redistribuci. Solidarita jako jeden z podstatných principů sociální nauky církve, „...pevná a trvalá odhodlanost usilovat o obecné blaho neboli dobro všech a jednoho každého, protože všichni jsme zodpovědni za všechny",29 je klíčovým aspektem společného dobra společnosti. V kontextu vyspělého Západu, kde solidarizační mechanismy přesáhly přiměřenou míru, se však více musíme tázat po jejím komplementárním korektivu - subsidiaritě. Nerespektování tohoto principu, který již encyklika Quadragesimo anno chápe jako důležitou zásadu, „která se nedá vyvrátit ani změnit“", má „...pak za následek těžké poškození a rozvrat sociálního rádu“ “30. V tomto kontextu encyklika Centesimus annus Jana Pavla II. kritizuje přebujelé zaopatřovací státy, které vedou ke zneužívání sociálních systémů, ztrátě morálních zdrojů a potenciálu k odpovědnosti, k nesmírnému zvyšování výdajů státu a tedy i k nepřiměřené redistribuci od "bohatých" $\mathrm{k}$ „chudým“31.

Na závěr vzpomeňme na slavný, nyní již taktéž zfilmovaný, román kontroverzní objektivistické filosofky ruského původu Ayn Randové Atlas Shrugged (1957). Pomiňme její problematická východiska radikálního individualismu a zpochybňování solidarity, které pravda nejsou plně konsistentní s pojetím křest́anské etiky, ale zaměřme se na její vyobrazení některých zásadních postřehů $\mathrm{k}$ fungování svobodné kapitalistické společnosti. Ve zmíněném románu jsou bohatí a schopní podnikatelé, manažeři, vědci a jiné kreativní a inteligentní osobnosti pod tak silným tlakem státních regulací, omezování a šikany, že se rozhodnou ze společnosti odejít. Randová považuje jejich kreativitu, iniciativu a další výjimečné a vzácné schopnosti za motor civilizace, s jejich „stávkou“ a postupným odchodem se pak celá civilizace hroutí a vše podstatné přestává fungovat, přičemž stát samotný není schopen kompenzovat tento deficit a plnit podstatné funkce. Obraz Atlase, který na svých ramenou nese břímě celku a který se pod strašlivým tlakem rozhodne pokrčit ramenem, nebo dokonce „ucuknout“, je impozantní a měl by nám být přinejmenším podnětem $\mathrm{k}$ docenění mimořádného významu, nepostradatelnosti takového typu lidí a k jejich morálnímu docenění, a to i z hledisek křestáanské etiky.

Uvedené podněty by nám měly být nápomocny $\mathrm{k}$ hledání respektu, obdivu, ocenění a k širšímu pochopení tzv. "bohatých", jež si můžeme samozřejmě nepřesně a neúplně ztotožnit s podnikatelskými elitami současnosti. Jde zejména o výše zmiňované „kreativní elity“, které svou pílí, inovací, invencí i štěstím výrazně přispívají k ekonomickému rozvoji. $\mathrm{Na}$ těchto tahounech ekonomiky, investorech, tvůrcích materiálních hodnot a pracovních míst, často též dárcích, mecenáších a přispěvatelích, leží nevídané břímě odpovědnosti a neúměrné zátěže, která rozhodně nebývá vykoupena společenským oceněním přínosu ke společnému dobru a už vưbec ne pocitem většího štěstí. Z kreativity, iniciativy a daní těchto lidí žijeme my mnozí, a proto hledět na ně jako na jakési parazity společnosti je zcela nepřesné a nezpơsobné. Při každém diferencovaném hodnocení morality bohatství a bohatých bychom tyto podněty měli vždy vzít v potaz. 


\section{Byznys jako povolání? Některé etické a duchovní souvislosti bohatství a moci}

Abstrakł Tento článek se v kontextu tématu „,pastorace bohatých a mocných“ zabývá problematikou ambivalentního postoje vưči bohatým a mocným tohoto světa. Na základě zásadních podnětů knihy Michaela Novaka Business as a Calling. Work and the Examined Life (1996) se pokouší interpretovat jejich obtižnou pozici a zároveň obhájit sféru byznysu. Téma je zasazeno do kontextu některých impulsư sociálního učení církve.

Klíčová slova byznys, povolání, pastorace, bohatství a moc, daně, redistribuce, sociální etika, sociální učení církve 